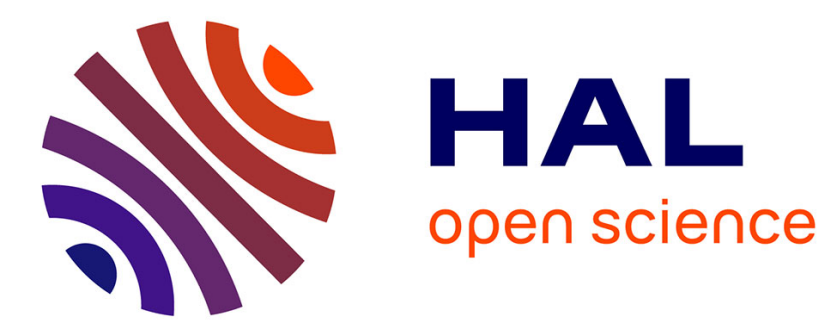

\title{
Asymmetric Organocatalytic Tandem/Domino Reactions Towards Access to Bioactive Products
}

Hélène Pellissier

\section{To cite this version:}

Hélène Pellissier. Asymmetric Organocatalytic Tandem/Domino Reactions Towards Access to Bioactive Products. Current Organic Chemistry, 2021, 25 (13), pp.1457-1471. 10.2174/1385272825666210208142427 . hal-03205965

\section{HAL Id: hal-03205965 https://hal.science/hal-03205965}

Submitted on 22 Apr 2021

HAL is a multi-disciplinary open access archive for the deposit and dissemination of scientific research documents, whether they are published or not. The documents may come from teaching and research institutions in France or abroad, or from public or private research centers.
L'archive ouverte pluridisciplinaire HAL, est destinée au dépôt et à la diffusion de documents scientifiques de niveau recherche, publiés ou non, émanant des établissements d'enseignement et de recherche français ou étrangers, des laboratoires publics ou privés. 


\title{
Asymmetric Organocatalytic Tandem/Domino Reactions to Access Bioactive Products
}

\author{
Hélène Pellissier ${ }^{1, *}$ \\ ${ }^{I}$ Aix Marseille Univ, CNRS, Centrale Marseille, iSm2, Marseille, France
}

\begin{abstract}
Tandem and domino reactions constitute economic methodologies to prepare complex molecules starting from simple materials. Especially, combining these powerful procedures to asymmetric catalysis allows direct access to many elaborated chiral products, including important key intermediates in total syntheses of important biologically active compounds. A range of various types of chiral organocatalysts have already been successfully applied to such syntheses. This review presents major developments in the total synthesis of bioactive products based on the use of enantioselective organocatalytic domino/tandem reactions as key steps. It is divided into three parts, dealing successively with syntheses based on organocatalytic asymmetric Michael-initiated domino reactions as key steps; aldol-initiated domino/tandem reactions and other domino reactions.
\end{abstract}

Keywords: Total synthesis, bioactive products, enantioselective domino/tandem reactions, organocatalysis, asymmetric catalysis, chirality.

\section{INTRODUCTION}

By avoiding costly purification of intermediates and protection/deprotection steps, one-pot synthetic procedures, such as domino and tandem processes [1], constitute a challenge in total synthesis. These powerful reactions allow easy and direct access to elaborated molecules starting from simple materials. Especially, a number of asymmetric organocatalytic versions of these economic methodologies have been employed as key steps in the synthesis of many bioactive products [2]. Indeed, organocatalytic processes are particularly adapted for the total synthesis of drugs related to the absence of metal contamination. By means of the impressive advent of asymmetric catalysis, many types of chiral green organocatalysts have been successfully used in such syntheses, spanning from common proline-derived secondary amines to cinchona alkaloids, phosphoric acids, and imidazolidinones, among others. Remarkably, very high enantioselectivities are commonly observed in these single processes. This review aims to summarize the major developments in the total synthesis of important bioactive products based on the use of asymmetric organocatalytic domino and tandem procedures. It is divided into three parts, dealing successively with syntheses based on organocatalytic asymmetric Michael-initiated domino reactions as key steps; aldol-initiated domino/tandem reactions and other domino reactions.

\section{MICHAEL-INITIATED DOMINO REACTIONS AS KEY STEPS}

In comparison with metal catalysts [3] presenting drawbacks such as toxicity, cost, moisture sensitivity, and recoverability, organocatalysts have the serious advantages to be cheaper, robust, non-toxic, more stable, readily available, and inert towards moisture and oxygen [4]. So far, various types of chiral organocatalysts have been applied to the total synthesis of a range of biologically important products, spanning from common proline-derived secondary amines to cinchona alkaloids, phosphoric acids, and imidazolidinones, among others. For example, in 1998, Terashima et al.. applied for the first time the concept of organocatalysis to the total synthesis of a drug, namely (-)-huperzine A, which is a naturally occurring potent reversible acetylcholinesterase inhibitor agent employed for the treatment of Alzheimer's disease [5]. Indeed, the key step of this short synthesis consisted an enantioselective domino Michael/aldol reaction between $\beta$-keto ester 1 and methacrolein 2 organocatalyzed by (-)-cinchonidine, leading to chiral key tricyclic product 3 as a mixture of three diastereomers (10:7:1) in $45 \%$ yield and $64 \%$ ee (Scheme 1). The latter was further converted through six supplementary steps (detailed in Scheme 1) into expected (-)-huperzine A. In the first step, domino product 3 was undergone dehydration in the presence of acetic acid to give product 4 in $77 \%$ yield. The second and third steps consisted of a Wittig reaction of $\mathbf{4}$ with ethylidenetriphenylphosphorane followed by isomerization of the ethylidene moiety to afford $(E)$-configured ethylenic product 5 in $88 \%$ yield ( 2 steps). Subsequent alkaline hydrolysis of this product led to the corresponding carboxylic acid 6 in $64 \%$ yield. Then, a modified Curtius rearrangement of the latter gave amide 7 in $66 \%$ yield, which was finally deprotected in the presence of TMSI to provide expected (-)-huperzine A in $81 \%$ yield.

In 2007 , total synthesis of a natural product (+)-palitantin, exhibiting anti-HIV, antibiotic, and antifungal activities, was disclosed by Hong et al. [6]. It was based on an enantioselective domino Michael/aldol reaction of two equivalents of $\alpha, \beta$-unsaturated aldehydes 8 catalyzed by L-proline, which afforded chiral cyclohexadiene carbaldehyde 9 in $70 \%$ yield and $95 \%$ ee (Scheme 2). This key intermediate was converted into expected $(+)$-palitantin through nine supplementary steps, beginning with its dihydroxylation into diol 10 achieved with $67 \%$ yield. Diol 10 was then pro- 

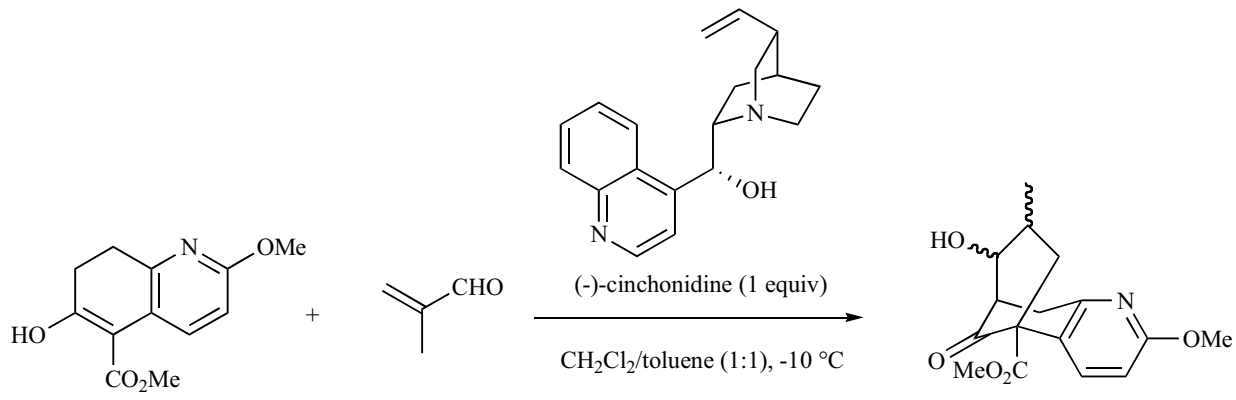

$$
3
$$

$45 \%, 10 \%$ de, $64 \%$ ee

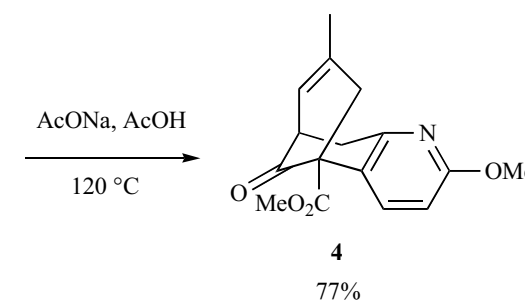

1) $\mathrm{PPh}_{3} \mathrm{EtBr}$, THF, $0^{\circ} \mathrm{C}$

2) $\mathrm{PhSH}$, AIBN, toluene, $85^{\circ} \mathrm{C}$

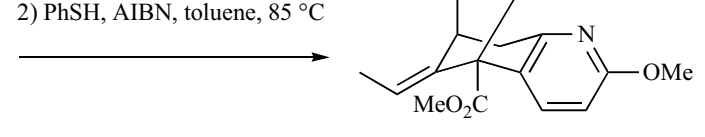

5

$88 \%$

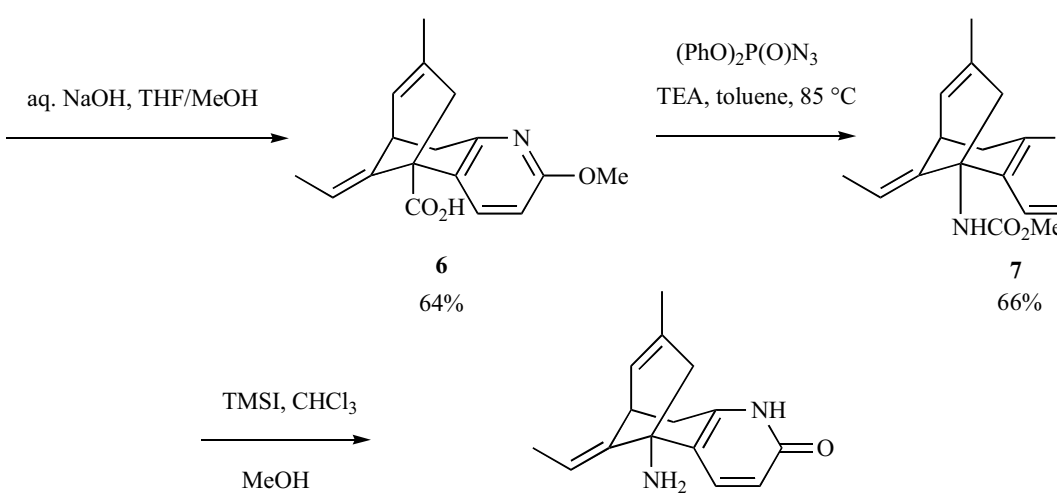

(-)-huperzine A

$81 \%$

mechanism for domino Michael/aldol reaction:<smiles>COc1ccc2c(n1)CCC(O)=C2C(=O)O</smiles>
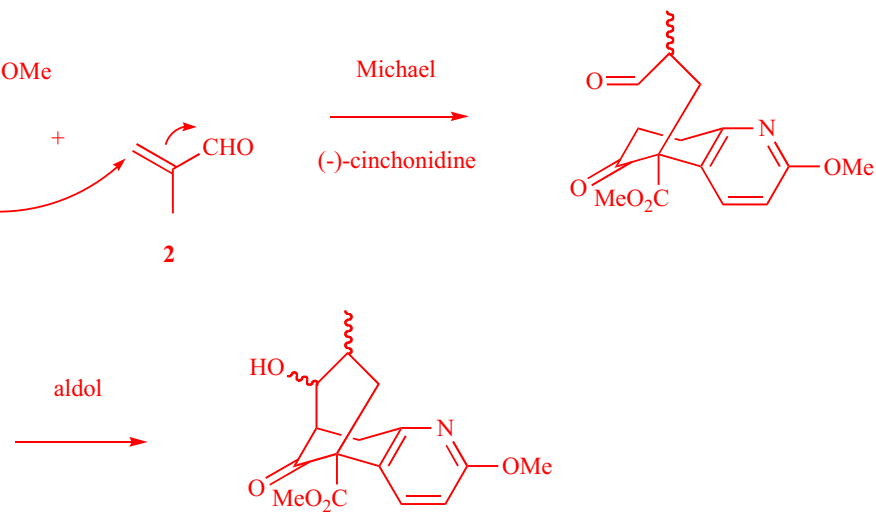

3

Scheme 1. Synthesis of (-)-huperzine A

tected into acetonide $\mathbf{1 1}$ with $85 \%$ yield, and then hydrogenation yielded aldehyde 12 in $65 \%$ yield. Wittig reaction of the latter with (2E)-hexenyl triphenylphosphonium bromide led to diene $\mathbf{1 3}$ in $85 \%$ yield. Further hydrolysis of $\mathbf{1 3}$ followed by the protection provided alcohol 27 in $83 \%$ yield. Subsequent oxidation of 14 by Dess-Martin periodinane, followed by deprotection of the TBS ether, provided acetonide 15 with 79\% yield. Finally, deprotection of acetonide $\mathbf{1 5}$ afforded (+)-palitantin in $95 \%$ yield.

In 2009, Rios et al. described a highly enantioselective synthesis of piperidines through domino Michael/cyclization reaction of $\alpha, \beta$-unsaturated aldehydes 16 with amidomalonates 17 catalyzed by 

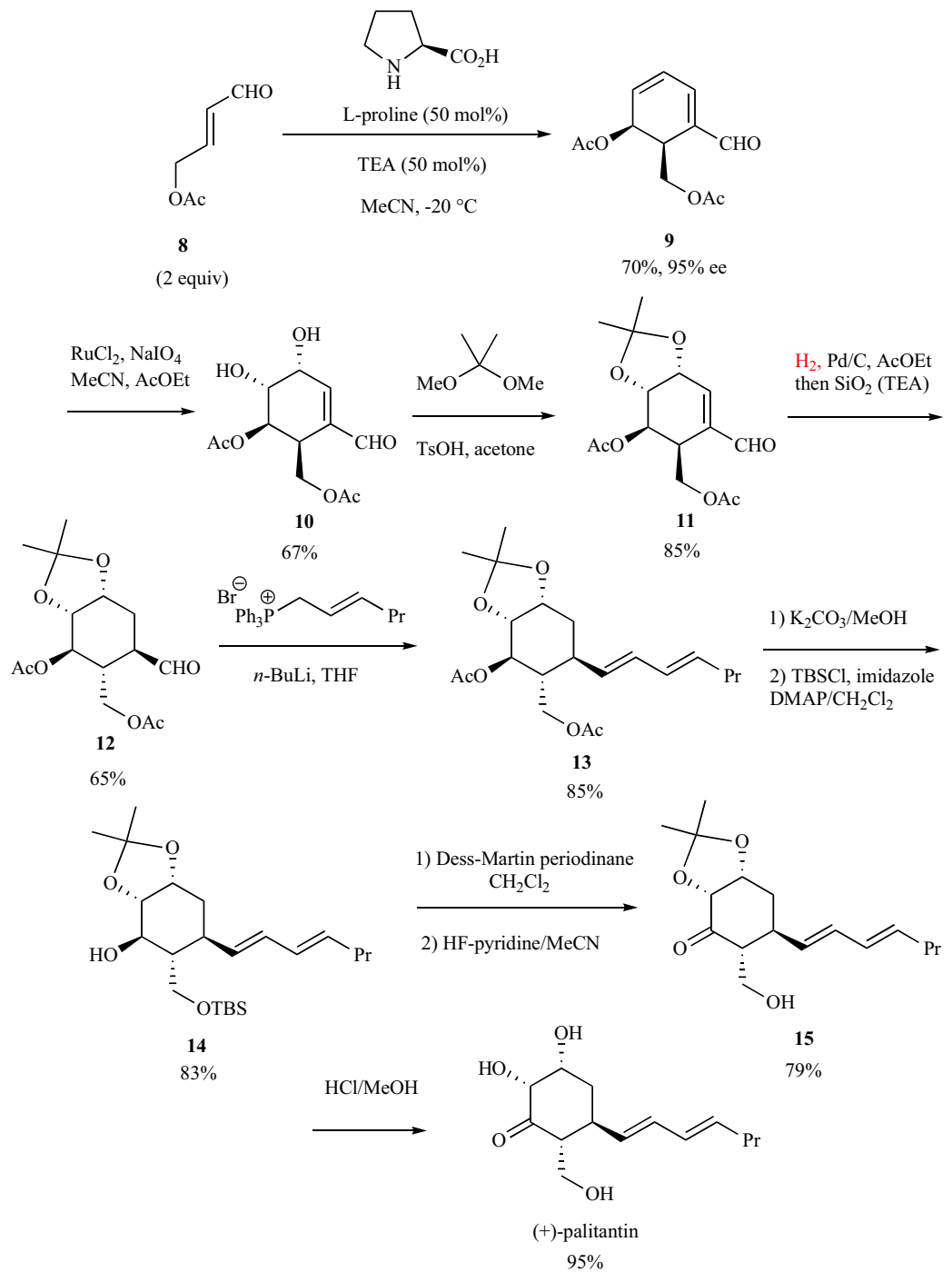

mechanism for domino Michael/aldol reaction

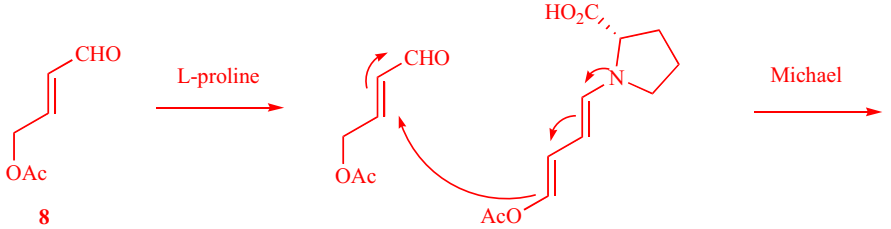

(2 equiv)
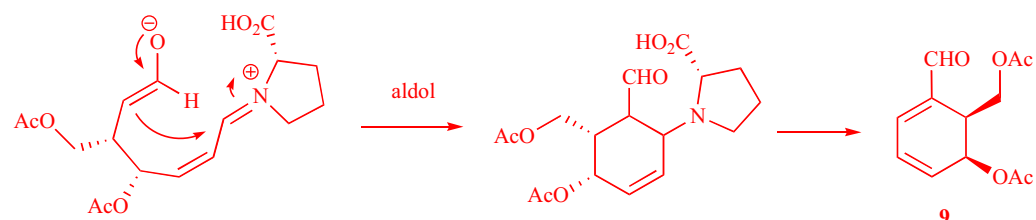

Scheme 2. Synthesis of (+)-palitantin.

chiral proline-derived amine $(R)-\mathbf{1 8}$ [7]. Among these products, chiral piperidine 19 , obtained with $84 \%$ yield, $66 \%$ de, and $90 \%$ ee, was used as a key intermediate in a synthesis of (-)-paroxetine which is a selective serotonine reuptake inhibitor drug. As shown in Scheme 3, domino product $\mathbf{1 9}$ was further converted into primary alcohol 20 with $76 \%$ yield by treatment with $\mathrm{BH}_{3}$. After subsequent protection of the latter into the corresponding mesylate $\mathbf{2 1}$ achieved with $97 \%$ yield, etherification with sesamol led to product $\mathbf{2 2}$ with $79 \%$ yield. Final deprotection of the $N$-benzyl group in $\mathbf{2 2}$ through hydrogenation afforded expected (-)-paroxetine in $90 \%$ yield.

In 2009, List and Michrowska employed another chiral imidazolidinone catalyst, such as $\mathbf{2 3}$, to promote enantioselective domino 
<smiles>O=C/C=C/c1ccc(F)cc1</smiles>

$+$<smiles>CCOC(=O)CC(=O)NCc1ccccc1</smiles><smiles>COC(c1ccccc1)(c1ccccc1)[C@H]1CCCN1</smiles>

(R)-18 (20 $\mathrm{mol} \%)$

$\mathrm{CF}_{3} \mathrm{CH}_{2} \mathrm{OH}$ KOAc, r.t.<smiles>O=C(O)C1C(=O)N(Cc2ccccc2)C(O)CC1c1ccc(F)cc1</smiles>

19<smiles>COC[C@H]1CN(Cc2ccccc2)CC[C@@H]1c1ccc(F)cc1</smiles><smiles>Oc1ccc2c(c1)OCO2</smiles>

mechanism for domino Michael/cyclization reaction:

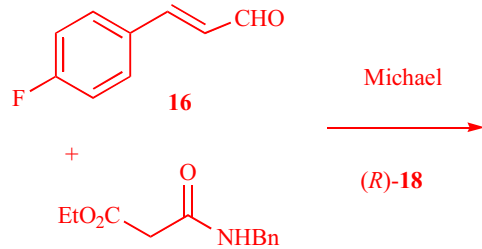

17<smiles>CC(=O)NC(=O)CC(C(=O)O)c1ccc(F)cc1</smiles>

cyclization<smiles>CCOC(=O)[C@H]1C(=O)N(Cc2ccccc2)C(O)C[C@H]1c1ccc(F)cc1</smiles>

Scheme 3. Synthesis of (-)-paroxetine.

reductive Michael/Michael cyclization reaction between aldehyde 24 and Hantzsch ester 25 [8]. This reaction allowed the synthesis of chiral ketoaldehyde $\mathbf{2 6}$ to be achieved. The latter was not isolated but directly submitted to $\mathrm{Sm}(\mathrm{O} i-\mathrm{Pr})_{3}$, undergoing isomerization followed by a highly diastereoselective Tishchenko reaction, which yielded ricciocarpin A, an anti schistosomiasis agent. Remarkably, this natural product was obtained as a single diastereo- $(>99 \%$ de) and enantiomer (>99\% ee) in $48 \%$ yield (Scheme 4). This synthesis of ricciocarpin A is the shortest reported so far.
In 2010, the first total synthesis of a natural and biologically active product (+)-conicol was reported by Hong et al. [9]. The key step of this synthesis consisted in an enantioselective domino oxaMichael/Michael reaction of 3-methylbut-2-enal 27 with (E)-2-(2nitrovinyl)-benzene-1,4-diol $\mathbf{2 8}$ upon catalysis with L-prolinederived secondary amine $(S)$-18, affording the corresponding enantiopure cycloadduct 29 in $76 \%$ yield (Scheme 5). This intermediate was further implicated in a domino Michael/aldol sequence catalyzed by the same organocatalyst through reaction with crotonalde- 

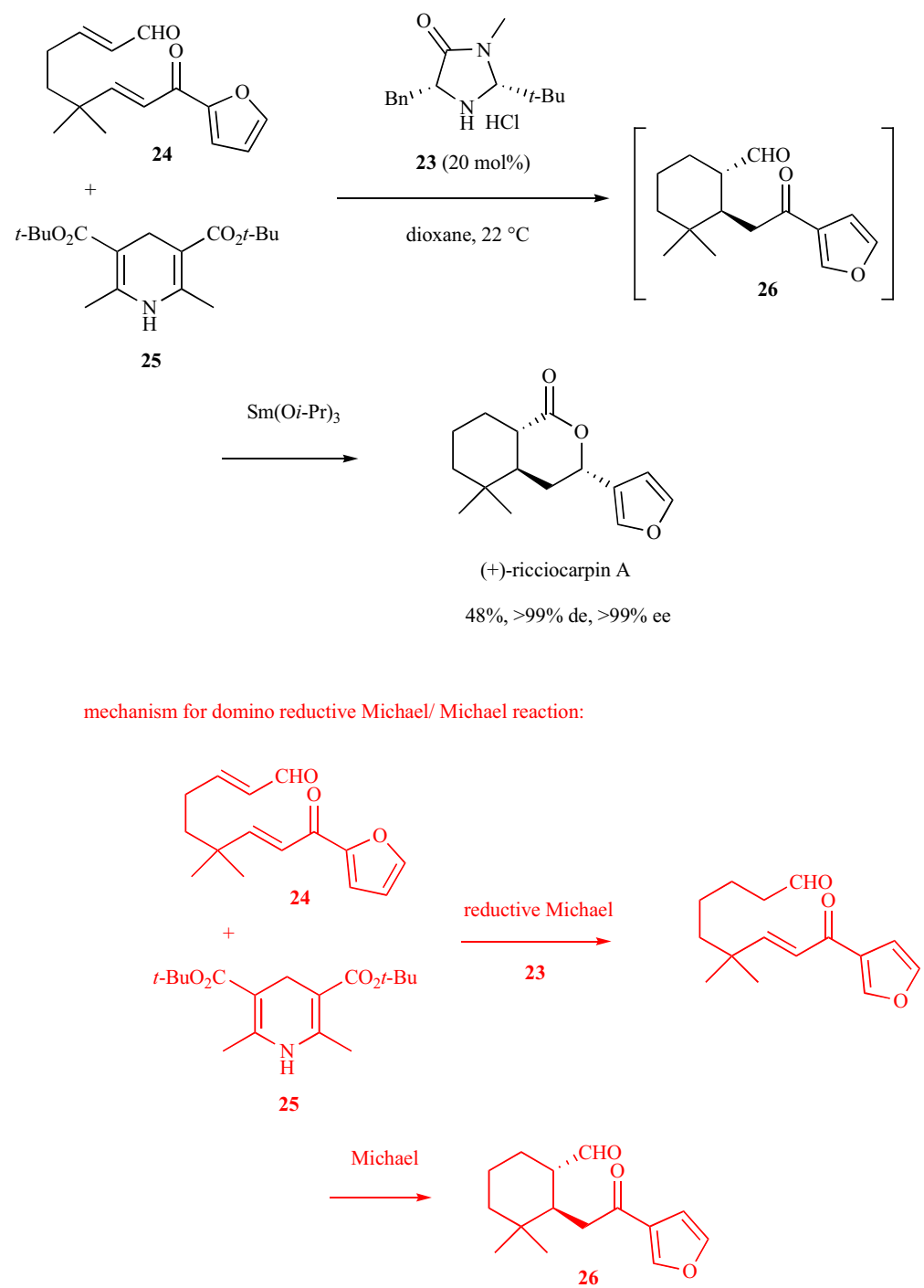

Scheme 4. Synthesis of ricciocarpin A.

hyde 30, leading to chiral hexahydro- $6 H$-benzo $[c]$ chromene $\mathbf{3 1}$ in $72 \%$ yield. The latter was submitted to decarbonylation in the presence of Wilkinson catalyst to give alkene $\mathbf{5 9}$ in 54\% yield. Then, hydrogenation of $\mathbf{3 2}$ provided $\mathbf{3 3}$ in $72 \%$ yield. Hydrolysis of the dimethoxymethyl group in $\mathbf{3 3}$ gave product $\mathbf{3 4}$ in $69 \%$ yield. A subsequent denitration elimination of $\mathbf{3 4}$ performed with DABCO led to $\mathbf{3 5}$ in $\mathbf{7 9 \%}$ yield. Reduction of $\mathbf{3 5}$ with DIBAL afforded primary alcohol 36 in $73 \%$ yield. Further acetylation of $\mathbf{3 6}$ yielded acetate 37 in 76\% yield, which finally underwent lithium reduction to provide expected $(+)$-conicol with $73 \%$ yield.

The antidepressant drug (-)-paroxetine was also synthesized in 2014 by Wang and Sun based on another organocatalytic asymmetric domino sequence [10]. This occurred with $72 \%$ yield and $91 \%$ ee between $\alpha, \beta$-unsaturated aldehyde $\mathbf{3 8}$ and malonic half-thioester 39 in the presence of L-proline-derived amine catalyst $\mathbf{4 0}$ through successive Michael addition, cyclization, and nucleophilic addition (Scheme 6). The formed chiral lactone 41 could be further converted into (-)-paroxetine in nine supplementary steps. Firstly, lactone $\mathbf{4 1}$ was submitted to nickel-catalyzed ring-opening reaction to give aldehyde $\mathbf{4 2}$ in $70 \%$ yield. A subsequent reduction of $\mathbf{4 2}$ afforded the corresponding chiral primary alcohol $\mathbf{4 3}$ in $87 \%$ yield. According to previously described works [11], alcohol $\mathbf{4 3}$ was me-

sylated and then undergone a reaction with benzylamine to give the corresponding lactame $\mathbf{4 4}$ in $82 \%$ yield. A subsequent carboxymethylation gave $\mathbf{4 5}$ in $88 \%$ yield, which was further reduced into primary alcohol $\mathbf{4 6}$ in $92 \%$ yield. Then, mesylation followed by reaction with sesamol afforded ether $\mathbf{4 7}$ in $80 \%$ yield. The latter was finally hydrogenated with $93 \%$ yield into expected (-)paroxetine.

In order to propose a novel route to estrogenic hormone estradiol, Hayashi et al. developed in 2017 an asymmetric total synthesis of estradiol methyl ether based on the use of an organocatalyst [12]. Indeed, the first step of the sequence consisted of an enantioselective domino Michael/aldol reaction of nitroalkane 48 with $\alpha, \beta$ unsaturated aldehyde 49 catalyzed by chiral amine $(S)$-18 to give the corresponding enantiopure bicyclic product 50. This highly functionalized bicyclo[4.3.0]nonane was not isolated but directly submitted to stereoselective addition of $\mathrm{KCN}$ to the aldehyde moiety, followed by the formation of the xanthate ester 51. Again, the latter was not isolated but directly dehydrated upon further addition of $\mathrm{SOCl}_{2}$ in the presence of pyridine to provide enantiopure cyclopentene $\mathbf{5 2}$ in $78 \%$ yield ( 3 steps). Then, reductive removal of both the nitro group and the xanthate ester moiety in $\mathbf{5 2}$ was accomplished simultaneously by treatment with $\mathrm{HSnBu}_{3}$ in the pres- 


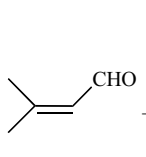

27<smiles>O=[N+]([O-])C=Cc1cc(O)ccc1O</smiles>

28

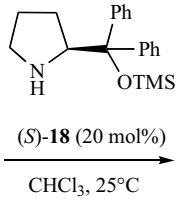<smiles>CC1(C)Oc2ccc(O)cc2[C@H](C=O)[C@H]1C=O</smiles>

29

$76 \%,>99 \%$ ee<smiles>COC(/C=C/C=O)OC</smiles>

$\mathrm{CHCl}_{3}$, r.t.

31

32

$72 \%$

$54 \%$

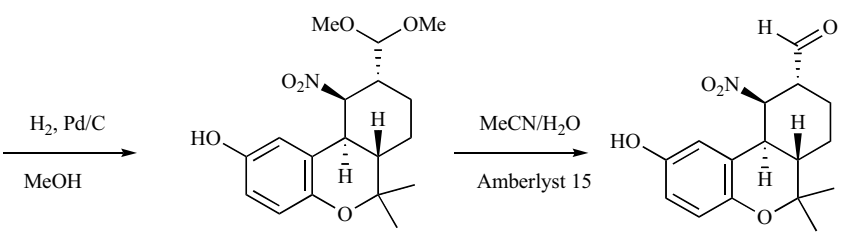

33

$72 \%$

$69 \%$<smiles>CC1(C)Oc2ccc(O)cc2[C@H]2C1=CC(C=O)=CC21[C@H]2CCC(CO)=CC2c2cc(O)ccc2OC1(C)C</smiles>

$\underset{\mathrm{TEA} / \mathrm{CH}_{2} \mathrm{Cl}_{2}}{\stackrel{\mathrm{AcCl} \text { DMAP }}{\longrightarrow}}$

$73 \%$

37

$\begin{array}{lc}37 & (+) \text {-conicol } \\ 6 \% & 73 \%\end{array}$

mechanism for domino oxa-Michael/Michael reaction:

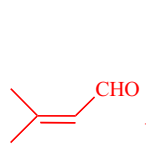

27<smiles>O=[N+]=CCc1cc(O)ccc1O</smiles>

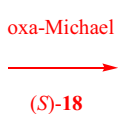

$(S)-\mathbf{1 8}$

(1)<smiles>CC1=CC2c3cc(O)ccc3OC(C)(C)[C@H]2CC1</smiles>

Scheme 5. Domino oxa-Michael/Michael reaction of 3-methylbut-2-enal with (E)-2-(2-nitrovinyl)-benzene-1,4-diol as key-step of synthesis of (+)-conicol.

ence of AIBN to afford intermediate $\mathbf{5 3}$ in $59 \%$ yield. Subsequently, diastereoselective reduction of the ketone moiety in $\mathbf{5 3}$ and conversion of the nitrile group into a formyl moiety were conducted in a single pot by successive treatment with $\mathrm{LiBHEt}_{3}$ and DIBAL to give hydroxy aldehyde $\mathbf{5 4}$ in $34 \%$ yield. The next step was the protection of $\mathbf{5 4}$ into the corresponding silyl ether $\mathbf{5 5}$ with a $59 \%$ yield. The latter was then submitted to a series of six reactions (detailed in Scheme 7) conducted in a single vessel, involving successively a Kraus-Pinnick oxidation, hydrogenation, an acyl chloride formation, a Friedel-Crafts acylation, a TIPS deprotection, and a reduction of benzyl ketone moiety to afford final enantiopure estradiol methyl ether in $55 \%$ overall yield (6 steps). It must be noted that this total synthesis employed a total of only five reaction vessels to be accomplished along with as low as four purification procedures. Later in 2018, the same authors improved this synthesis, increasing the overall yield from $5 \%$ to $6.8 \%$ [13].

\section{ALDOL-INITIATED DOMINO/TANDEM REACTIONS AS KEY STEPS}

In 2008, a synthesis of the most important member of the vitamin E family, namely $\alpha$-tocopherol, was developed by Woggon et al., including an enantioselective organocatalyzed domino al- 
<smiles>O=C/C=C/c1ccc(F)cc1</smiles><smiles>O=C(O)CC(=O)[Hg]</smiles>

39<smiles>CCC(CC(=O)O)c1ccc(F)cc1</smiles><smiles>O=C1C[C@H](c2ccc(F)cc2)CCN1[NH2+][Na]</smiles>

$82 \%$
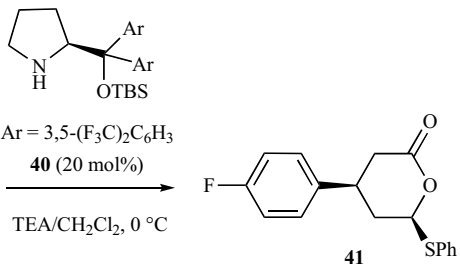

$72 \%, 91 \%$ ee

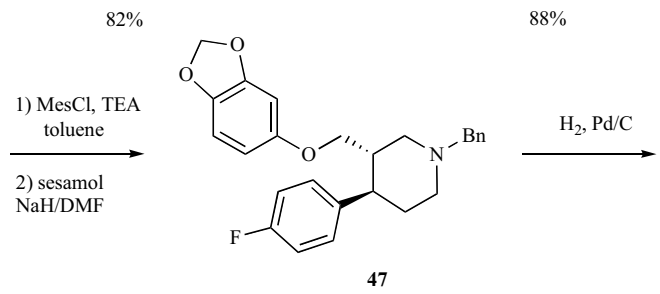

$80 \%$

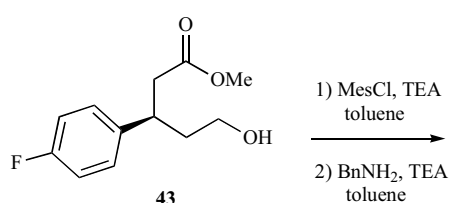

$87 \%$

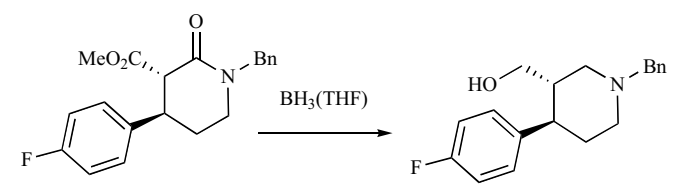

45

46
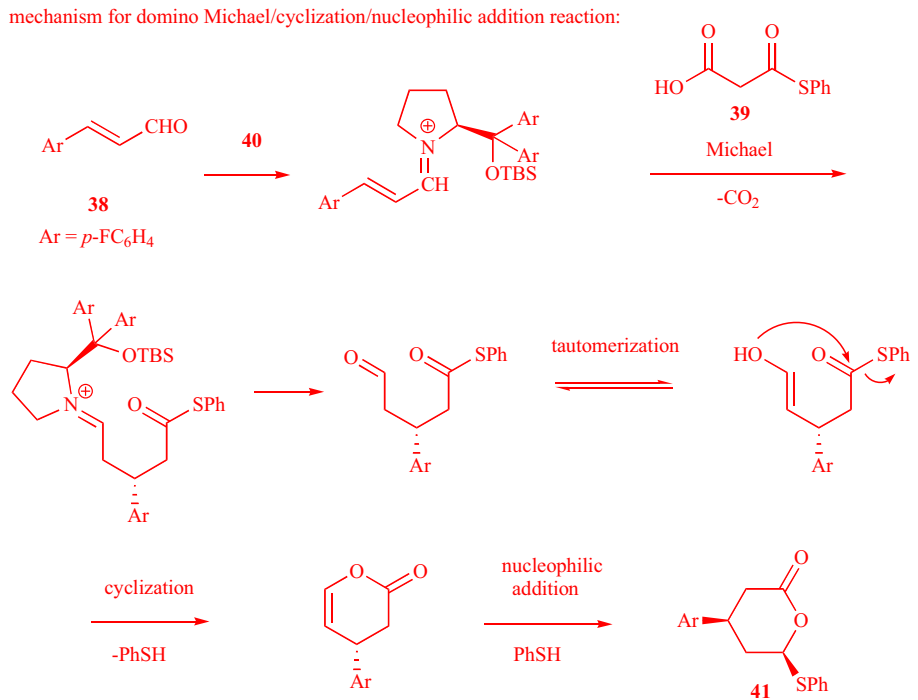

Scheme 6. Synthesis of (-)-paroxetine.

dol/oxa-Michael/hemiacetalization reaction (Scheme 8) [14]. Proline-derived amine catalyst $\mathbf{5 6}$ was employed to promote this reaction between $\alpha, \beta$-unsaturated aldehyde $\mathbf{5 7}$ and salicylic acid $\mathbf{5 8}$, which led to a $58 \%$ yield of chiral tricyclic hemiaminal $\mathbf{5 9}$ as almost single diastereomer $(97 \%$ de). This key product could be transformed into desired $\alpha$-tocopherol in only four steps. The first one consisted of its oxidation with PCC into lactone $\mathbf{6 0}$ achieved with $90 \%$ yield. Then, this benzylic lactone was quantitatively hydrogenated into carboxylic acid 61, which was further submitted to a Barton decarboxylation procedure to give $\alpha$-tocopherol ether
62 in $72 \%$ yield and $94 \%$ de. Final cleavage of the methyl ether of 62 by treatment with $\mathrm{BF}_{3}\left(\mathrm{SMe}_{2}\right) / \mathrm{AlCl}_{3}$ yielded expected $\alpha$ tocopherol with $84 \%$ yield.

In 2018, an enantioselective tandem double aldol reaction catalyzed by simple L-proline and achiral thiomorpholinium trifluoroacetate 63 was developed by Aggarwal et al. as a key step in a total synthesis of $\Delta^{12}$-prostaglandin $\mathrm{J}_{3}$ exhibiting anti-leukemic properties [15]. This one-pot two-step aldol dimerization of succinaldehyde $\mathbf{6 4}$ followed by hemiacetalization and dehydration led to the corresponding chiral bicyclic enal intermediate 65 in $29 \%$ yield, 
<smiles>CC1(CC[N+](=O)[O-])C(=O)CCC1=O</smiles><smiles>COc1ccc(/C=C/C=O)cc1</smiles><smiles>[Na]OC(c1ccccc1)(c1ccccc1)C1CCCN1</smiles>

(S)-18 (10 mol\%)

$\mathrm{PhCO}_{2} \mathrm{H}, \mathrm{H}_{2} \mathrm{O}$ $i$-PrOH, r.t.

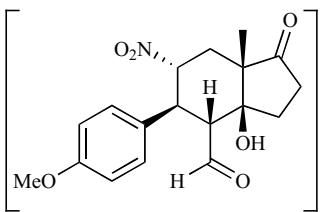

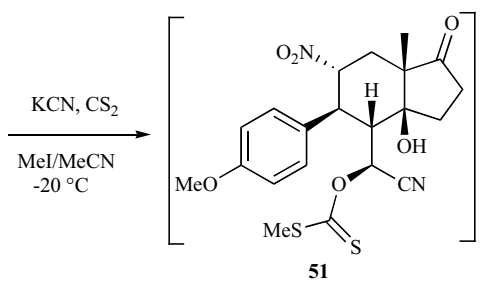<smiles>COc1ccc([C@H]2CC[C@]3(C)C(=O)CC=C3C2CC#N)cc1</smiles>

53

$59 \%$

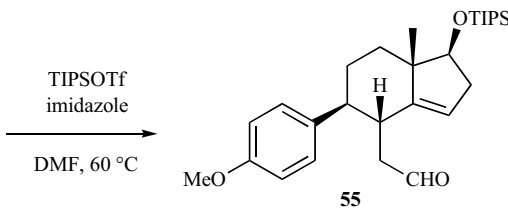

$59 \%$
1) $\mathrm{LiBHEt}_{3}$

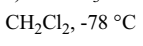

2) DIBAL

$\mathrm{CH}_{2} \mathrm{Cl}_{2}, 0^{\circ} \mathrm{C}$

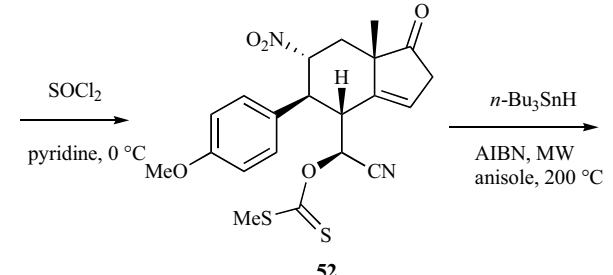

$78 \%$ (3 steps), $>99 \%$ ee<smiles>COc1ccc(C2CCC3(C)C(=CC[C@@H]3O)C2(CC=O)CC=O)cc1</smiles>

1) $\mathrm{NaClO}_{2}, \mathrm{NaH}_{2} \mathrm{PO}_{4}$ 2-methyl-2-butene $t-\mathrm{BuOH} / \mathrm{H}_{2} \mathrm{O}, 0^{\circ} \mathrm{C}$ 2) $\mathrm{H}_{2}, \mathrm{Pd}(\mathrm{OH})$

3) $(\mathrm{COCl})_{2} / \mathrm{CH}_{2} \mathrm{Cl}_{2}$ 4) $\mathrm{AlCl}_{3} / \mathrm{CH}_{2} \mathrm{Cl}_{2}$ 5) $\mathrm{MeOH}$ 6) $\mathrm{H}_{2}, \mathrm{Pd}(\mathrm{OH})$

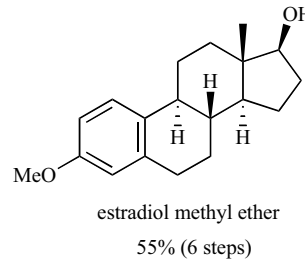

mechanism for domino Michael/aldol reaction:<smiles>COc1ccc(/C=C/C=O)cc1</smiles><smiles></smiles>

(S)-18

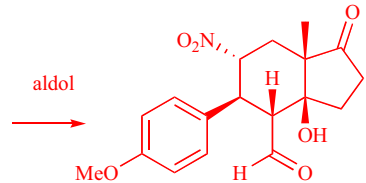

Scheme 7. Synthesis of estradiol methyl ether.

$60 \%$ de, and $99 \%$ ee (Scheme 9). The synthetic utility of this product was demonstrated in its conversion through ten supplementary steps into $\Delta^{12}$-prostaglandin $\mathrm{J}_{3}$. The sequence began with the oxidation of the aldehyde group in $\mathbf{6 5}$ into carboxylic acid $\mathbf{6 6}$ with a $74 \%$ yield. Then, the latter was converted into acyl azide 67 in $80 \%$ yield. Heating 67 in toluene affected a Curtius rearrangement leading to an isocyanate, which was trapped with benzyl alcohol to give carbamate $\mathbf{6 8}$ in $90 \%$ yield. The latter was then reduced to hemiacetal 69 in the presence of DIBAL with a $98 \%$ yield. Then, Wittig reaction of 69 with phosphonium salt 70 provided the corresponding enamide, which was not isolated but directly hydrolyzed and then dehydrated to afford enone $\mathbf{7 1}$ in $81 \%$ yield. The latter was further converted into $t$-butyl ester $\mathbf{7 2}$ in $83 \%$ yield. This product subsequently underwent aldol condensation with $\beta$-boryl aldehyde $\mathbf{7 3}$ to give alcohol $\mathbf{7 4}$ as a mixture of epimers. The latter was treated with $\mathrm{MesCl}$ and TEA to afford the corresponding mesylate, which underwent elimination in the presence of DBU to produce the corresponding $E$-configured elimination product exclusively. The resulting boronic ester was oxidized into secondary alcohol $\mathbf{7 5}$ using $\mathrm{NaBO}_{3}\left(\mathrm{H}_{2} \mathrm{O}\right)_{4}$ in $23 \%$ overall yield ( 3 steps). Finally, treatment of 75 with $\mathrm{HBF}_{4}$ yielded an expected $\Delta^{12}$-prostaglandin $\mathrm{J}_{3}$ in $75 \%$ yield.

\section{OTHER DOMINO REACTIONS AS KEY STEPS}

Later in 2006, chiral phosphoric acid 76 was applied by Rueping et al. to promote the key step of the synthesis of three bioactive tetrahydroquinoline alkaloids, such as (+)-cuspareine, (+)galipinine, and $(+)$-angustureine [16]. Indeed, Brønsted acid 76 was found to catalyze highly enantioselectively, the double transfer hydrogenation of 2-substituted quinolines 77a-c with Hantzsch 


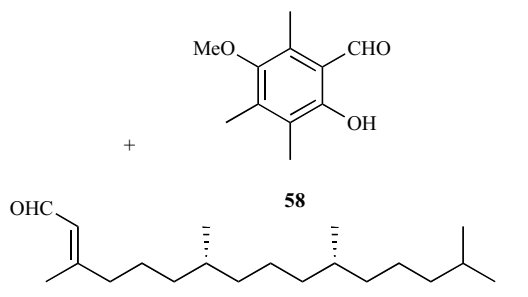

57

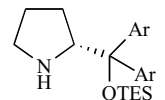

$\mathrm{Ar}=3,5-\left(\mathrm{CF}_{3}\right)_{2} \mathrm{C}_{6} \mathrm{H}_{3}$ $56(30 \mathrm{~mol} \%)$

toluene, r.t.

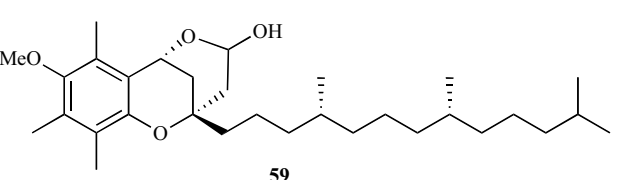

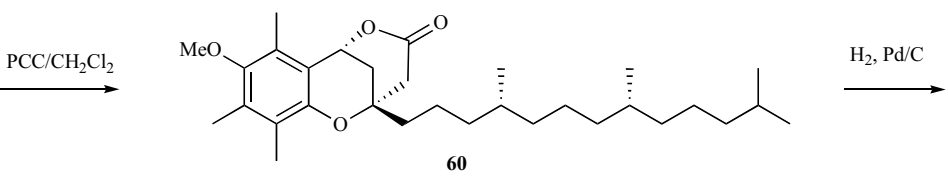

$90 \%$

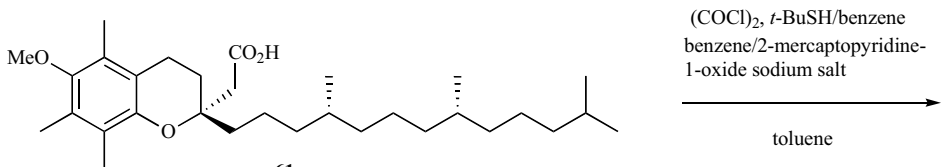

$>99 \%$

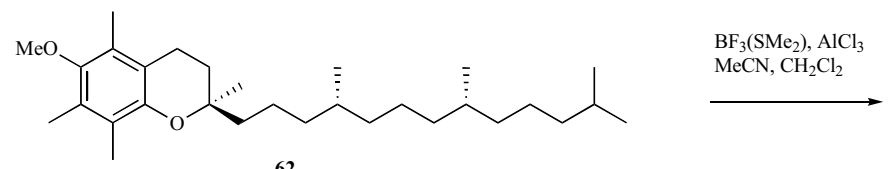

62

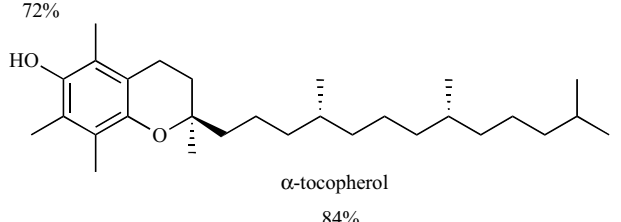

$84 \%$

mechanism for domino aldol/oxa-Michael/hemiacetalization reaction:<smiles>COc1c(C)c(C)c(O)c(C=O)c1C</smiles>

58<smiles>CC(=CC=O)CCC[C@@H](C)CCC[C@@H](C)CCCC(C)C</smiles><smiles>COc1c(C)c(C)c(O)c(C(O)CC(CC=O)(CC=O)CCC[C@@H](C)CCC[C@@H](C)CCCC(C)C)c1C</smiles>

oxa-Michael

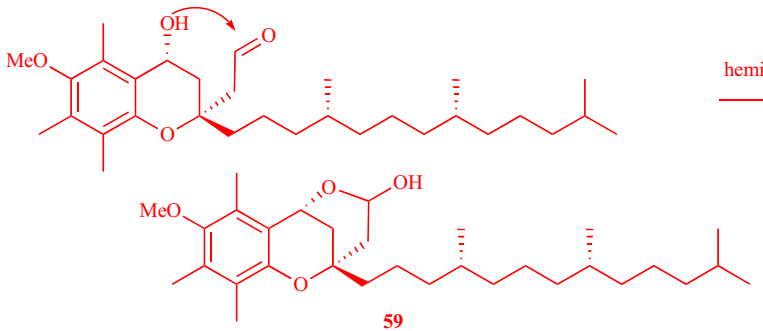

Scheme 8. Synthesis of $\alpha$-tocopherol.

ester 78. As shown in Scheme 10, this one-pot double-transfer hydrogenation afforded the corresponding chiral tetrahydroquinolines 79a-c in both high yields (79-89\%) and enantioselectivities (90$91 \%$ ee). The latter were further $N$-methylated to give expected (+)cuspareine, $(+)$-galipinine, and $(+)$-angustureine in excellent yields (90-95\%).
In 2006, Itoh et al. reported synthesis of the highly toxic alkaloid (+)-coniine, which is known to induce curare-type paralysis [17]. The synthesis included an asymmetric three-component Mannich reaction organocatalyzed by L-proline. It involved acetone $\mathbf{8 0}$, $p$-anisidine 81, and 5-hydroxypentanal $\mathbf{8 2}$ as substrates, leading to chiral Mannich product $\mathbf{8 3}$ in $76 \%$ yield and $91 \%$ ee (Scheme 11). The conversion of this key product into desired $(+)$-coniine was 


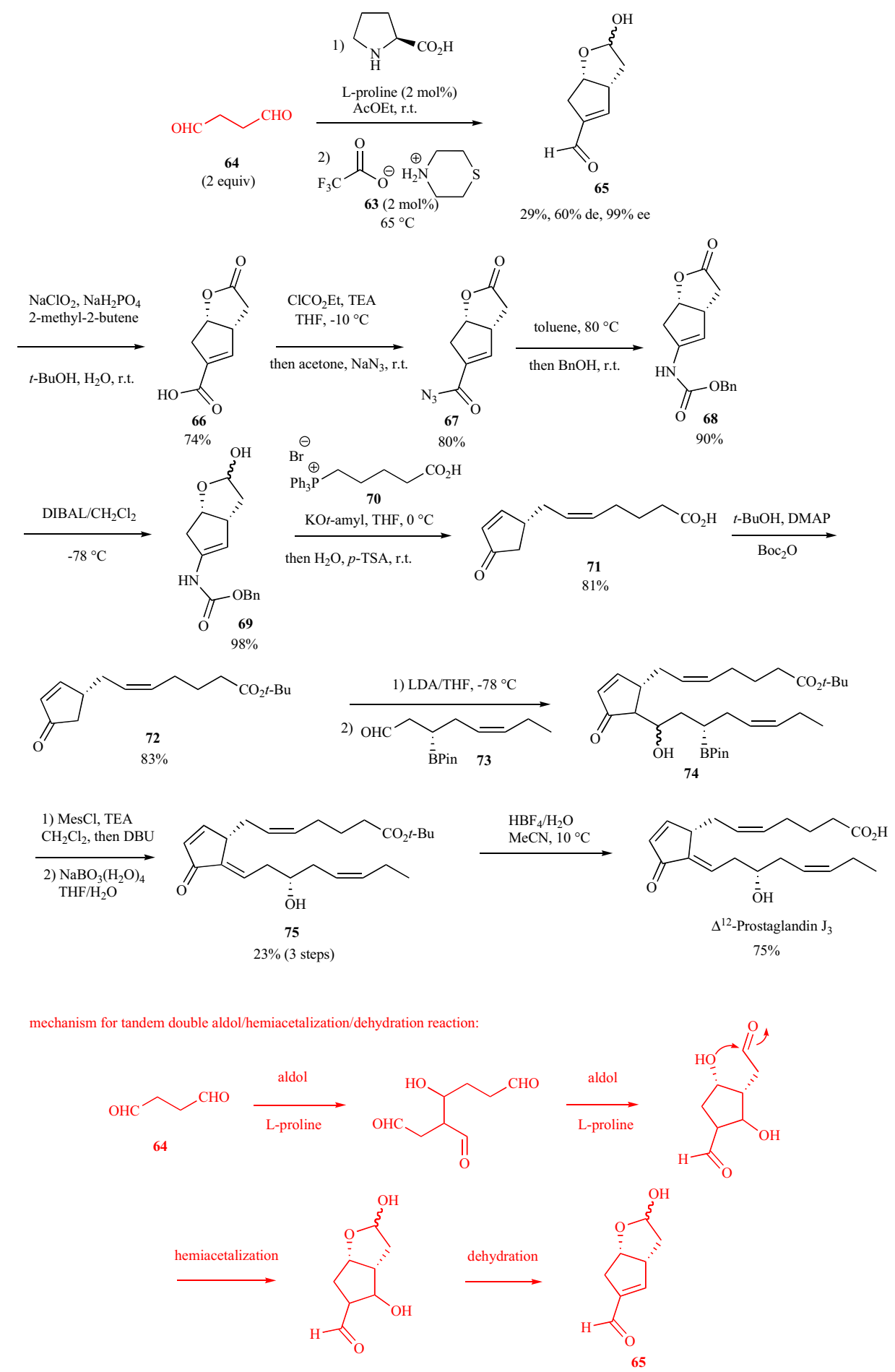

Scheme 9. Synthesis of $\Delta^{12}$-prostaglandin $\mathrm{J}_{3}$.

achieved through seven steps, beginning with its cyclization into piperidine $\mathbf{8 4}$ through Mitsunobu reaction followed by reduction of the latter with $\mathrm{NaBH}_{4}$ to give $\mathbf{8 5}$ in $66 \%$ yield (2 steps). Subsequently, intermediate 85 was mesylated and then reduced with $\mathrm{LiAlH}_{4}$ to give 86 in $82 \%$ yield ( 2 steps). Then, CAN oxidation of 86 followed by $\mathrm{Cbz}$ protection led to product 87 in $86 \%$ yield (2 steps). Finally, catalytic hydrogenation of $\mathbf{8 7}$ afforded (+)-coniine hydrochloride in quantitative yield.

The indole skeleton is widely expanded in medicinal chemistry [18]. In 2009, MacMillan et al. reported total synthesis of natural and biologically active (-)-minfiensine, the key step of which was a highly enantioselective organocatalytic domino Diels-Alder/amine cyclization reaction building the central tetracyclic pyrroloindoline framework of (-)-minfiensine [19]. As illustrated in Scheme 12, in the presence of chiral imidazolidinone catalyst $\mathbf{8 8}$, 2-vinylindole $\mathbf{8 9}$ reacted with propynal $\mathbf{9 0}$ to give the corresponding chiral tetracyclic pyrroloindoline 91 in $87 \%$ yield and $96 \%$ ee. This carbamate was further converted through only five steps into (-)-minfiensine. The first step consisted of the treatment of 91 by TESOTf to provide silyl ether 92 in $84 \%$ yield. Reductive amination of this secon- 

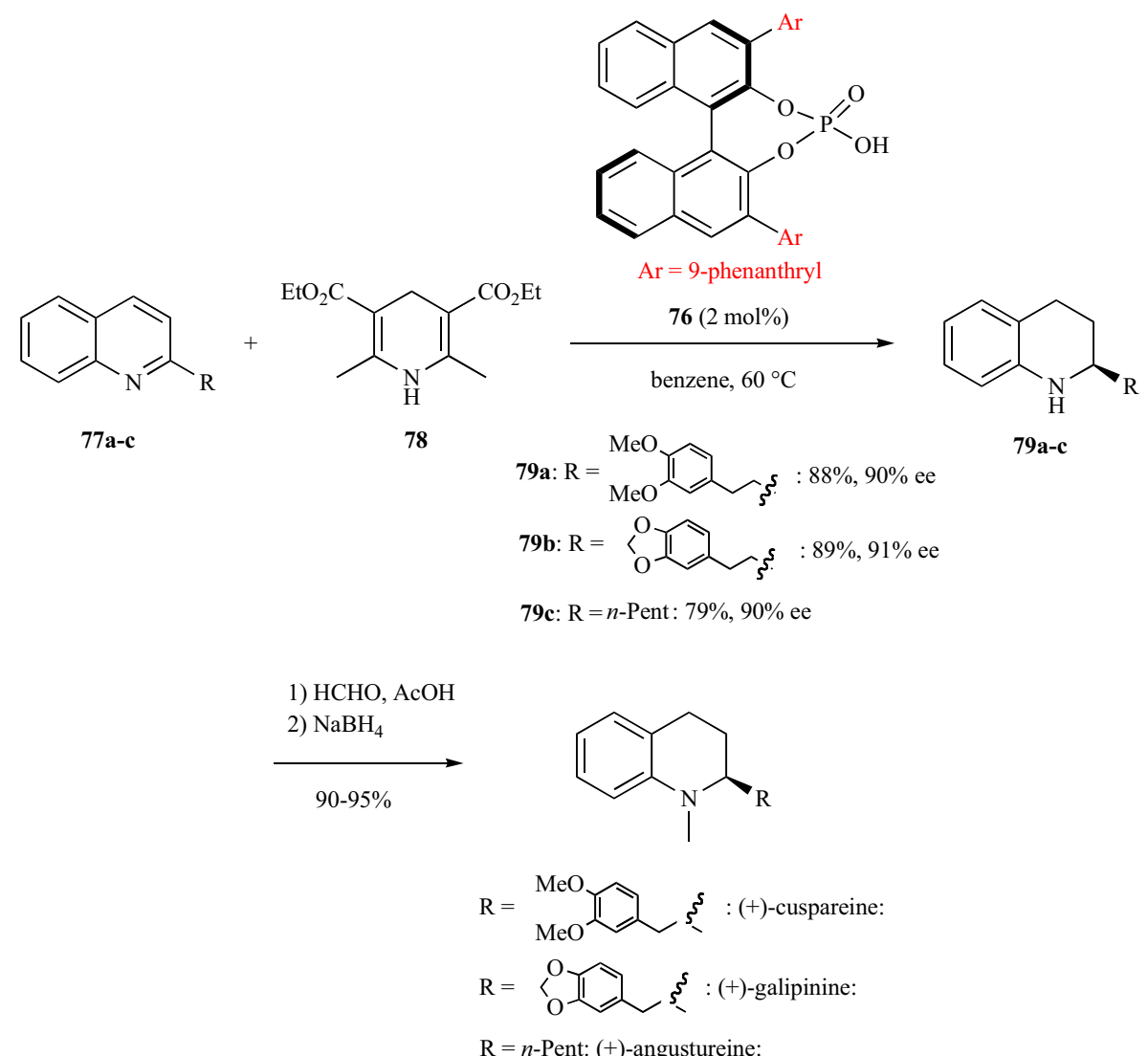

Scheme 10. Synthesis of $(+)$-cuspareine, $(+)$-galipinine, and $(+)$-angustureine.

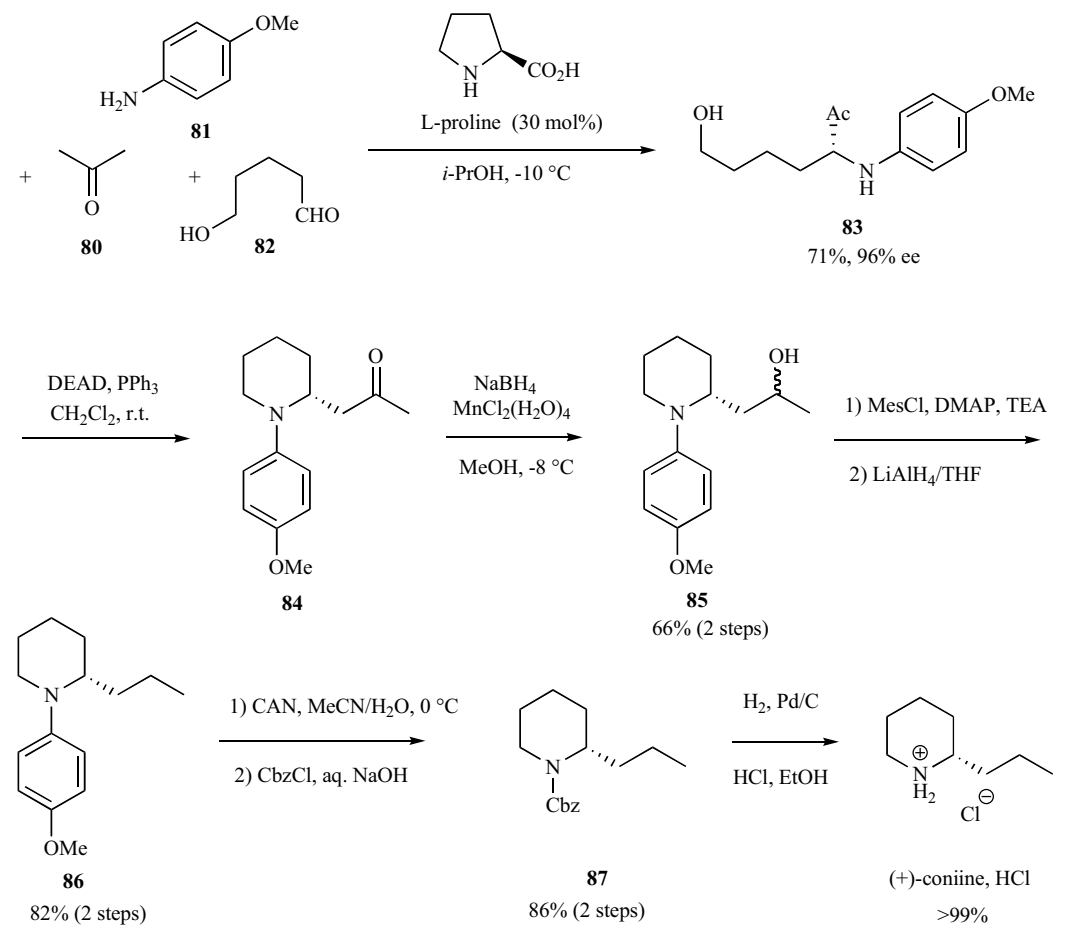

Scheme 11. Synthesis of $(+)$-coniine.

dary amine 92 with butynal $t$-butyl sulfide was performed in the presence of $\mathrm{NaBH}(\mathrm{OAc})_{3}$ to give intermediate 93 in $96 \%$ yield. The latter was further undergone to a radical cyclization, affording al- lene 94 with a $61 \%$ yield. Hydrogenation of this allene followed by deprotection in the presence of TFA led to final (-)-minfiensine in $90 \%$ yield and $>20: 1 E / Z$ diastereoselectivity. 

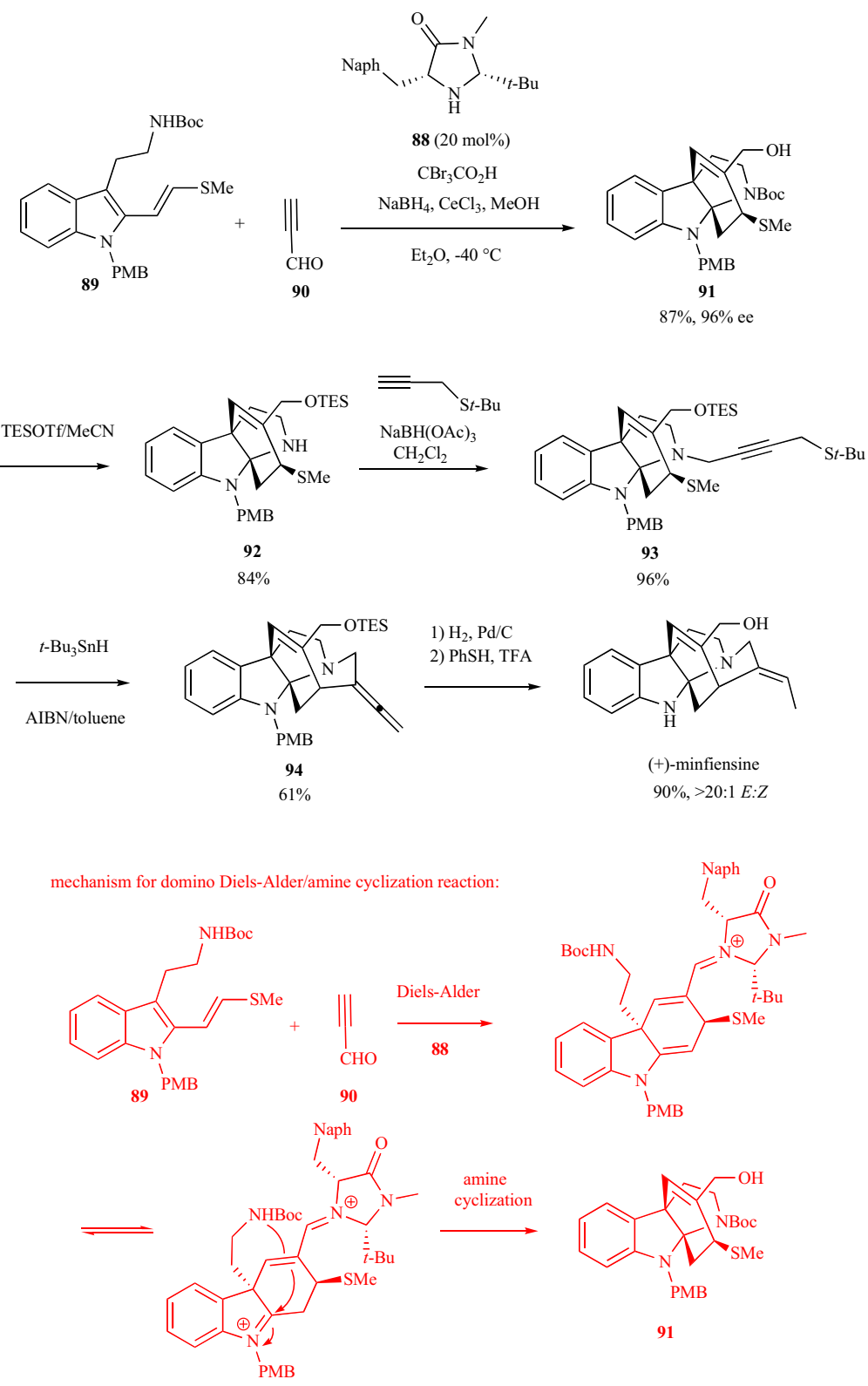

Scheme 12. Synthesis of (-)-minfiensine.

\section{CONCLUSION}

This review collects major advances in the total synthesis of bioactive products using enantioselective organocatalytic domino/tandem processes as key steps. It demonstrates that a variety of one-pot asymmetric reactions catalyzed by chiral green organocatalysts have already allowed a diversity of biologically important products and drugs to be economically synthesized. The diversity of these single vessel reactions reflects that of the catalysts employed to promote them. Indeed, various chiral organocatalysts have already been successfully applied to the total synthesis of pharmaceutical and bioactive products. The most employed are prolinederived secondary amines which allow the syntheses of products as different as (+)-conicol with $>99 \%$ ee, $(+)$-coniine with $91 \%$ ee, $(+)$-paroxetine with $91 \%$ ee, estradiol methyl ether with $>99 \%$ ee, $\Delta^{12}$-prostaglandin $\mathrm{J}_{3}$ with $99 \%$ ee, $(+)$-palitantin with $95 \%$ ee, and $\alpha$-tocopherol with $97 \%$ de. Other chiral amine catalysts, such as imidazolidinones, have been used in the key steps of total syntheses of (+)-minfiensine with $96 \%$ ee, and (+)-ricciocarpin A with $>99 \%$ ee. Chiral phosphoric acids were successfully applied in the total syntheses of $(+)$-cuspareine, $(+)$-galipinine, and $(+)$-angustureine with $91 \%$ ee, while cinchona alkaloids were employed to promote the key steps in the synthesis of (-)-huperzine A with $64 \%$ ee. In accordance with the huge advent of asymmetric catalysis, more and more organocatalyzed asymmetric domino and tandem methodologies will undoubtedly be applied as economic key steps in the total synthesis of other bioactive products in the near future.

\section{LIST OF ABBREVIATIONS}

$\begin{array}{ll}\mathrm{AIBN} & =\text { Azobisisobutyronitrile } \\ \mathrm{Ar} & =\text { Aryl } \\ \mathrm{Bn} & =\text { Benzyl } \\ \mathrm{Boc} & =\text { tert-butoxycarbonyl } \\ \mathrm{CAN} & =\text { Ceric ammonium nitrate } \\ \mathrm{Cbz} & =\text { Benzyloxycarbonyl } \\ \mathrm{DABCO} & =1,4 \text {-diazabicyclo[2.2.2]octane }\end{array}$




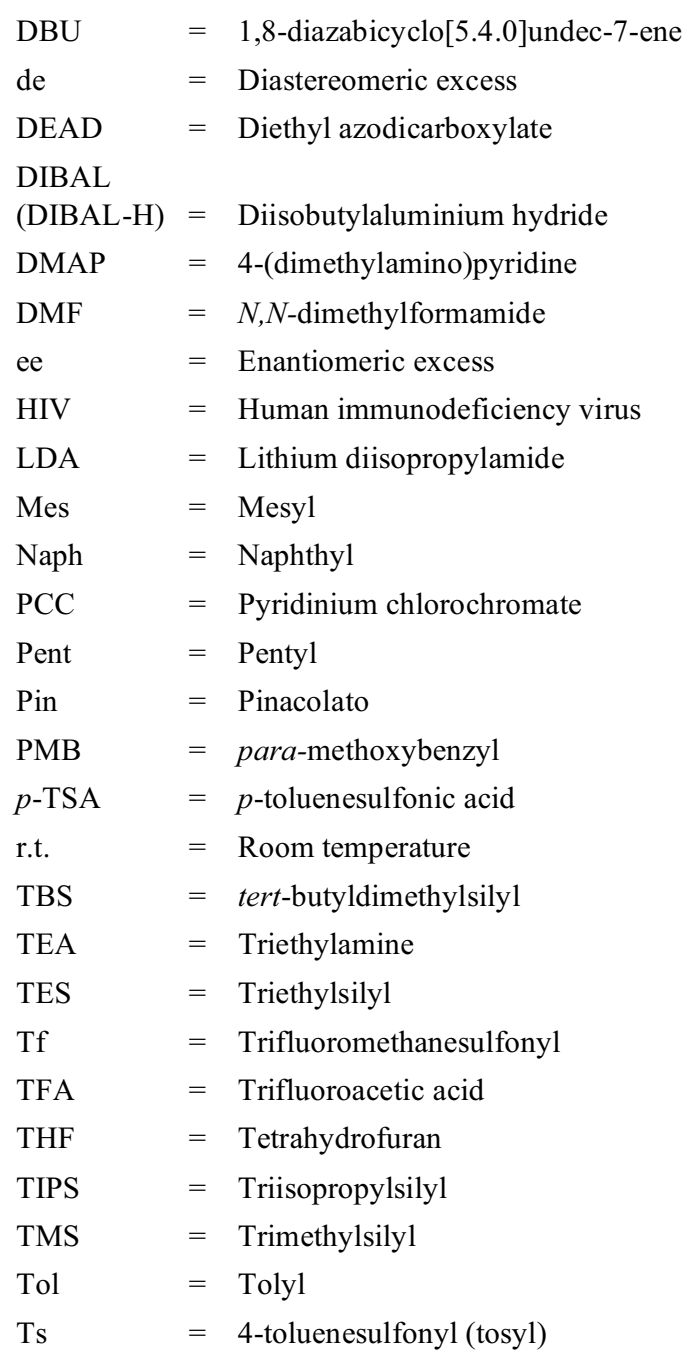

(e) Tietze, L.F.; Modi, A. Multicomponent domino reactions for the synthesis of biologically active natural products and drugs. Med. Res. Rev., 2000, 20(4), 304-322.

http://dx.doi.org/10.1002/1098-1128(200007)20:4<304::AID-

MED3>3.0.CO;2-8 PMID: 10861729

(f) Dalko, P.I.; Moisan, L. In the golden age of organocatalysis. Angew. Chem. Int. Ed. Engl., 2004, 43(39), 5138-5175.

http://dx.doi.org/10.1002/anie.200400650 PMID: 15455437

(g) Ramón, D.J.; Yus, M. Asymmetric multicomponent reactions (AMCRs): the new frontier. Angew. Chem. Int. Ed. Engl., 2005, 44(11), 1602-1634.

http://dx.doi.org/10.1002/anie.200460548 PMID: 15719349

(h) Zhu, J.; Bienaymé, H. Multicomponent Reactions; Wiley-VCH: Weinheim, 2005.

http://dx.doi.org/10.1002/3527605118

(i) Tietze, L.F.; Brasche, G.; Gericke, K. Domino Reactions in Organic Synthesis; Wiley-VCH: Weinheim, 2006.

http://dx.doi.org/10.1002/9783527609925

(j) Pellissier, H. Asymmetric domino reactions. Part B: reactions based on the use of chiral catalysts and biocatalysts. Tetrahedron, 2006, 62, 2143-2173. http://dx.doi.org/10.1016/j.tet.2005.10.041

(k) Pellissier, H. Asymmetric domino reactions. Part A: reactions based on the use of chiral auxiliaries. Tetrahedron, 2006, 62, 1619-1665.

http://dx.doi.org/10.1016/j.tet.2005.10.040

(1) Enders, D.; Grondal, C.; Hüttl, M.R.M. Asymmetric organocatalytic domino reactions. Angew. Chem. Int. Ed. Engl., 2007, 46(10), 1570-1581.

http://dx.doi.org/10.1002/anie.200603129 PMID: 17225236

(m) Guillena, G.; Ramon, D.J.; Yus, M. Organocatalytic enantioselective multicomponent reactions (OEMCRs). Tetrahedron Asymmetry, 2007, 18, 693-700.

http://dx.doi.org/10.1016/j.tetasy.2007.03.002

(n) Touré, B.B.; Hall, D.G. Natural product synthesis using multicomponent reaction strategies. Chem. Rev., 2009, 109(9), 4439-4486.

http://dx.doi.org/10.1021/cr800296p PMID: 19480390

(o) Orru, R.V.A.; Ruijter, E. Synthesis of Heterocycles via Multicomponent Reactions, Topics in Heterocyclic Chemistry; Springer: Berlin, 2010.

(p) Pellissier, H. Recent developments in asymmetric organocatalytic domino reactions. Adv. Synth. Catal., 2012, 354, 237-294.

http://dx.doi.org/10.1002/adsc.201100714

(q) Clavier, H.; Pellissier, H. Recent developments in enantioselective metalcatalyzed domino reactions. Adv. Synth. Catal., 2012, 354, 3347-3403. http://dx.doi.org/10.1002/adsc.201200254

(r) Pellissier, H. Stereocontrolled domino reactions. Chem. Rev., 2013, $113(1), 442-524$.

http://dx.doi.org/10.1021/cr300271k PMID: 23157479

(s) Pellissier, H. Asymmetric Domino Reactions; Royal Society of Chemistry: Cambridge, 2013

(t) Tietze, L.F. Domino Reactions - Concepts for Efficient Organic Synthesis; Wiley-VCH: Weinheim, 2014

http://dx.doi.org/10.1002/9783527671304

(u) Zhu, J.; Wang, Q.; Wang, M. Multicomponent Reactions in Organic Synthesis; Wiley: Weinheim, 2014

http://dx.doi.org/10.1002/9783527678174

(v) Herrera, R.P.; Marques-Lopez, E. Multicomponent Reactions: Concepts and Applications for Design and Synthesis; Wiley: Weinheim, 2015.

(w) Snyder, S.A. Science of Synthesis. Applications of Domino Transformations in Organic Synthesis; Thieme Verlag: Stuttgart, 2016.

(x) Pellissier, H. Recent developments in enantioselective metal-catalyzed domino reactions. Adv. Synth. Catal., 2016, 358, 2194-2259.

http://dx.doi.org/10.1002/adsc.201600462

(y) Pellissier, H. Recent developments in enantioselective metal-catalyzed domino reactions. Adv. Synth. Catal., 2019, 361, 1733-1755.

http://dx.doi.org/10.1002/adsc.201801371

(z) Pellissier, H. Asymmetric Metal Catalysis in Enantioselective Domino Reactions; Wiley: Weinheim, 2019.

http://dx.doi.org/10.1002/9783527822539

[2] (a) Ho, T-L.Tandem Organic Reactions; Wiley: New York, 1992.

(b) Fukumoto, K. Effective Ring Formations and Natural Product Syntheses.

Synth. Org. Chem. Jpn., 1994, 52, 2-18.

(c) Bunce, R.A. Recent advances in the use of tandem reactions for organic synthesis. Tetrahedron, 1995, 51, 13103-13159.

http://dx.doi.org/10.1016/0040-4020(95)00649-S

(d) Padwa, A.; Weingarten, M.D. Cascade processes of metallo carbenoids. Chem.Rev., 1996, 96(1), 223-270.

http://dx.doi.org/10.1021/cr950022h PMID: 11848752

(e) Denmark, S.E.; Thorarensen, A. Tandem [4+2]. Chem. Rev., 1996, 96(1), 137-166. [3+2].

http://dx.doi.org/10.1021/cr940277f PMID: 11848747

(f) Nicolaou, K.C.; Montagnon, T.; Snyder, S.A. Tandem reactions, cascade sequences, and biomimetic strategies in total synthesis. Chem. Commun. (Camb.), 2003, (5), 551-564.

http://dx.doi.org/10.1039/b209440c PMID: 12669826

(g) Tietze, L.F.; Rackelmann, N. Domino reactions in the synthesis of heterocyclic natural products and analogs. Pure Appl. Chem., 2004, 76, 19671983. 
http://dx.doi.org/10.1351/pac200476111967

(h) Nicolaou, K.C. Edmonds, DJ. Bulger, P.G. Cascade reactions in total synthesis. Angew. Chem. Int. Ed.Engl., 2006, 45(43), 7134-7186.

http://dx.doi.org/10.1002/anie.200601872 PMID: 17075967

(i) Chapman, C.J.; Frost, C.G. Tandem and domino catalytic strategies for enantioselective synthesis. Synthesis, 2007, 2007(1), 1-21.

http://dx.doi.org/10.1055/s-2006-950379

(j) Padwa, A.; Bur, S.K. The domino way to heterocycles. Tetrahedron, 2007, 63(25), 5341-5378.

http://dx.doi.org/10.1016/j.tet.2007.03.158 PMID: 17940591

(k) D'Souza, D.M.; Müller, T.J.J. Multi-component syntheses of heterocycles by transition-metal catalysis. Chem. Soc. Rev., 2007, 36(7), 1095-1108.

http://dx.doi.org/10.1039/B608235C PMID: 17576477

(1) de Figueiredo, R.M.; Christmann, M. Organocatalytic synthesis of drugs and bioactive natural products. Eur. J. Org. Chem., 2007, 2575-2600.

http://dx.doi.org/10.1002/ejoc.200700032

(m) Alba, A-N.; Companyo, X.; Viciano, M.; Rios, R. Organocatalytic domino reactions. Curr. Org. Chem., 2009, 13, 1432-1474.

http://dx.doi.org/10.2174/138527209789055054

(n) Sorenson, E.J.; Davies H.M.L. Special issue on: rapid formation of molecular complexity in organic synthesis. Chem. Soc. Rev., 2009, 38, 29693276

(o) Nicolaou, K.C.; Chen, J.S. The art of total synthesis through cascade reactions. Chem. Soc. Rev., 2009, 38(11), 2993-3009.

http://dx.doi.org/10.1039/b903290h PMID: 19847336

(p) Biggs-Houck, J.E.; Younai, A.; Shaw, J.T. Recent advances in multicomponent reactions for diversity-oriented synthesis. Curr. Opin. Chem. Biol., 2010, 14(3), 371-382

http://dx.doi.org/10.1016/j.cbpa.2010.03.003 PMID: 20392661

(q) Ruiz, M.; López-Alvarado, P.; Giorgi, G.; Menéndez, J.C. Domino reactions for the synthesis of bridged bicyclic frameworks: fast access to bicyclo[n.3.1]alkanes. Chem. Soc. Rev., 2011, 40(7), 3445-3454.

http://dx.doi.org/10.1039/c1cs15018a PMID: 21483949

(r) Albrecht, Ł.; Jiang, H.; Jørgensen, K.A. A simple recipe for sophisticated cocktails: organocatalytic one-pot reactions--concept, nomenclature, and future perspectives. Angew. Chem. Int. Ed. Engl., 2011, 50(37), 8492-8509.

http://dx doi.org/10.1002/anie 201102522 PMID: 21826772

(s) Vaxelaire, C.; Winter, P.; Christmann, M. One-pot reactions accelerate the synthesis of active pharmaceutical ingredients. Angew. Chem. Int. Ed Engl., 2011, 50(16), 3605-3607.

http://dx.doi.org/10.1002/anie.201100059 PMID: 21374777

(t) de Graaff, C.; Ruijter, E.; Orru, R.V.A. Recent developments in asymmetric multicomponent reactions. Chem. Soc. Rev., 2012, 41(10), 3969-4009. http://dx.doi.org/10.1039/c2cs15361k PMID: 22546840

(u) Ardkhean, R.; Caputo, D.F J ; Morrow, S.M ; Shi, H.; Xiong, Y ; Anderson, E.A. Cascade polycyclizations in natural product synthesis. Chem. Soc Rev., 2016, 45(6), 1557-1569.

http://dx.doi.org/10.1039/C5CS00105F PMID: 2679179

(v) Hayashi, Y. Pot economy and one-pot synthesis. Chem. Sci. (Camb.), 2016, 7(2), 866-880.

http://dx.doi.org/10.1039/C5SC02913A PMID: 28791118

[3] (a) Noyori, R. Asymmetric Catalysts in Organic Synthesis; Wiley-VCH: New-York, 1994

(b) Beller, M.; Bolm, C. Transition Metals for Organic Synthesis; WileyVCH: Weinheim, 1998

http://dx.doi.org/10.1002/9783527619399

(c) Ojima, I. Catalytic Asymmetric Synthesis; Wiley-VCH, 2000.

http://dx.doi.org/10.1002/0471721506

(d) Beller, M.; Bolm, C. Metals for Organic Synthesis, $2^{\text {nd }}$ ed.; Wiley-VCH: Weinheim, 2004

(e) Tietze, L.F.; Ila, H.; Bell, H.P. Enantioselective palladium-catalyzed transformations. Chem. Rev., 2004, 104(7), 3453-3516.

http://dx.doi.org/10.1021/cr030700x PMID: 15250747

(f) Ramón, D.J.; Yus, M. In the arena of enantioselective synthesis, titanium complexes wear the laurel wreath. Chem. Rev., 2006, 106(6), 2126-2208. http://dx.doi.org/10.1021/cr040698p PMID: 16771446

(g) Pellissier, H. Enantioselective Nickel-catalysed Transformations; The Royal Society of Chemistry: Cambridge, 2016.

http://dx.doi.org/10.1142/p1065

(h) Pellissier, H. Enantioselective Titanium-catalysed Transformations; Imperial College Press: London, 2016.

http://dx.doi.org/10.1142/p1065

(i) Pellissier, H. Enantioselective silver-catalyzed transformations. Chem. Rev., 2016, 116(23), 14868-14917.

http://dx.doi.org/10.1021/acs.chemrev.6b00639 PMID: 27960274

(j) Pellissier, H. Enantioselective magnesium-catalyzed transformations. Org. Biomol. Chem., 2017, 15(22), 4750-4782.

http://dx.doi.org/10.1039/C7OB00903H PMID: 28513750

(k) Pellissier, H. Recent developments in enantioselective cobalt-catalyzed transformations. Coord. Chem. Rev., 2018, 360, 122-168.

http://dx.doi.org/10.1016/j.ccr.2018.01.013

(l) Pellissier, H. Syntheses of natural and biologically relevant products through asymmetric metal-catalyzed domino reactions. A review. Org. Prep. Proced.Int., 2019, 51, 311-344. http://dx.doi.org/10.1080/00304948.2019.1590681

(a) Knoevenagel, E. Über eine Darstellungsweise des Benzylidenacetessigester. Chem.Ber., 1896, 29, 172-174.

http://dx.doi.org/10.1002/cber.18960290133

(b) Eder, U.; Sauer, G.; Wiechert, R. New type of asymmetric cyclization to optically active steroid CD partial structures. Angew. Chem. Int. Ed. Engl., 1971, 10, 496-497.

http://dx.doi.org/10.1002/anie.197104961

(c) Hajos, Z.G.; Parrish, D.R. Asymmetric synthesis of bicyclic intermediates of natural product chemistry. J. Org. Chem., 1974, 39, 1615-1621.

http://dx.doi.org/10.1021/jo00925a003

(d) Dalko, P.I.; Moisan, L. Enantioselective organocatalysis. Angew. Chem. Int. Ed.Engl., 2001, 40(20), 3726-3748.

http://dx.doi.org/10.1002/1521-3773(20011015)40:20<3726::AID-

ANIE3726>3.0.CO-2-D PMID: 11668532

(e) List, B. Proline-catalyzed asymmetric reactions. Tetrahedron, 2002, 58, 5573-5590.

http://dx.doi.org/10.1016/S0040-4020(02)00516-1

(f) Berkessel, A.; Gröger, H. Asymmetric Organocatalysis-From Biomimetic Concepts to Powerful Methods for Asymmetric Synthesis; Wiley-VCH: Weinheim, 2005.

http://dx.doi.org/10.1002/3527604677

(g) Taylor, M.S.; Jacobsen, E.N. Asymmetric catalysis by chiral hydrogenbond donors. Angew. Chem. Int. Ed.Engl., 2006, 45(10), 1520-1543.

http://dx.doi.org/10.1002/anie.200503132 PMID: 16491487

(h) Enders, D.; Niemeier, O.; Henseler, A. Organocatalysis by N-heterocyclic carbenes. Chem. Rev., 2007, 107(12), 5606-5655.

http://dx.doi.org/10.1021/cr068372z PMID: 17956132

(i) Dalko, P.I. Enantioselective Organocatalysis; Wiley-VCH: Weinheim, 2007.

http://dx.doi.org/10.1002/9783527610945

(j) Pellissier, H. Asymmetric organocatalysis. Tetrahedron, 2007, 63, 92679331.

http://dx.doi.org/10.1016/j.tet.2007.06.024

(k) Doyle, A.G.; Jacobsen, E.N. Small-molecule H-bond donors in asymmetric catalysis. Chem. Rev., 2007, 107(12), 5713-5743.

http://dx doi.org/10.1021/cr068373r PMID: 18072808

(1) Gaunt, M.J.; Johansson, C.C.C.; McNally, A.; Vo, N.T. Enantioselective organocatalysis. Drug Discov. Today, 2007, 12(1-2), 8-27.

http://dx.doi.org/10.1016/j.drudis.2006.11.004 PMID: 17198969

(m) List, B. Special issue on organocatalysis. Chem. Rev., 2007, 107, 54135883.

(n) Akiyama, T. Stronger Brønsted acids. Chem. Rev., 2007, 107(12), 57445758 .

http://dx.doi.org/10.1021/cr068374j PMID: 17983247

(o) Mukherjee, S.; Yang, J.W.; Hoffmann, S.; List, B. Asymmetric enamine catalysis. Chem. Rev., 2007, 107(12), 5471-5569.

http://dx.doi.org/10.1021/cr0684016 PMID: 18072803

(p) Wurz, R.P. Chiral dialkylaminopyridine catalysts in asymmetric synthesis. Chem. Rev. 2007, 107(12), 5570-5595.

http://dx.doi.org/10.1021/cr068370e PMID: 18072804

(q) Davie, E.A.; Mennen, S.M.; Xu, Y.; Miller, S.J. Asymmetric catalysis mediated by synthetic peptides. Chem. Rev., 2007, 107(12), 5759-5812.

http://dx.doi.org/10.1021/cr068377w PMID: 18072809

(r) Yu, X.; Wang, W. Hydrogen-bond-mediated asymmetric catalysis. Chem. Asian J., 2008, 3(3), 516-532.

http://dx.doi.org/10.1002/asia.200700415 PMID: 18286564

(s) Dondoni, A.; Massi, A. Asymmetric organocatalysis: from infancy to adolescence. Angew. Chem. Int Ed. Engl, 2008, 47(25), 4638-4660.

http://dx.doi.org/10.1002/anie.200704684 PMID: 18421733

(t) Melchiorre, P.; Marigo, M.; Carlone, A.; Bartoli, G. Asymmetric aminocatalysis--gold rush in organic chemistry. Angew. Chem. Int. Ed. Engl., 2008 , 47(33), 6138-6171.

http://dx.doi.org/10.1002/anie.200705523 PMID: 18666089

(u) Gong, L. Special topic: asymmetric organocatalysis. Chin. Sci. Bull., 2010, 55(17), 1699-1842.

(v) Kampen, D.; Reisinger, C.M.; List, B. Chiral Brønsted acids for asymmetric organocatalysis. Top. Curr. Chem., 2010, 291, 395-456.

http://dx.doi.org/10.1007/128_2009_1 PMID: 21494945

(w) Pellissier, H. Recent Developments in Asymmetric Organocatalysis; Royal Society of Chemistry: Cambridge, 2010.

(x) Mahrwald, R. Enantioselective Organocatalysed Reactions; Springer: Berlin, 2011, I and II,

(y) Volla, C.M.R.; Atodiresei, I.; Rueping, M. Catalytic C-C bond-forming multi-component cascade or domino reactions: pushing the boundaries of complexity in asymmetric organocatalysis. Chem. Rev., 2014, 114(4), 23902431 .

http://dx.doi.org/10.1021/cr400215u PMID: 24304297

(z) Chauhan, P.; Mahajan, S.; Kaya, U.; Hack, D.; Enders, D. Bifunctional amine-squaramides: powerful hydrogen-bonding organocatalysts for asymmetric domino/cascade reactions. Adv. Synth. Catal., 2015, 357, 253281

http://dx.doi.org/10.1002/adsc.201401003 
(aa) Vetica, F.; Marcia de Figueiredo, R.; Orsini, M.; Tofani, D.; Gasperi, T. Recent advances in organocatalytic cascade reactions toward the formation of quaternary stereocenters. Synthesis, 2015, 47, 2139-2184.

http://dx.doi.org/10.1055/s-0034-1378742

(ab) Tian, L.; Luo, Y.-C.; Hu, X.-Q.; Xu, P.-F. Recent developments in the synthesis of chiral compounds with quaternary centers by organocatalytic cascade reactions. Asian J. Org. Chem., 2016, 5, 580-607.

http://dx.doi.org/10.1002/ajoc.201500486

(ac) Nayak, S.; Panda, P.; Bhakta, S.; Mishra, S. K.; Mohapatra, S. Current advances of organocatalytic Michael-Michael cascade reaction in the synthesis of highly functionalized cyclic molecules. RSC $A d v$., 2016, 6, 9615496175 .

http://dx.doi.org/10.1039/C6RA21191G

(ad) Qin, Y.; Zhu, L.; Luo, S. Organocatalysis in inert C-H bond functionalization. Chem Rev, 2017, 117(13), 9433-9520.

http://dx.doi.org/10.1021/acs.chemrev.6b00657 PMID: 28697602

(ae) Chanda, T.; Zhao, J. C.-G. Recent progress in organocatalytic asymmetric domino transformations. Adv. Synth. Catal., 2018, 360, 2-79.

http://dx.doi.org/10.1002/adsc.201701059

(af) Guo, H.; Fan, Y. C.; Sun, Z., Wu, Y.; Kwon, O. Phosphine Organocatalysis. Chem. Rev., 2018, 118, 10049-10293.

(ag) Sahoo, B. M.; Banik, B. K. Organocatalysis: trends of drug synthesis in medicinal chemistry. Curr. Organocatal., 2019, 6, 92-105.

http://dx doi.org/10 2174/2213337206666190405144423

[5] Kaneko, S.; Yoshino, T.; Katoh, T.; Terashima, S. Synthetic studies of Huperzine A and its fluorinated analogues. 1. Novel asymmetric syntheses of an enantiomeric pair of Huperzine A. Tetrahedron, 1998, 54, 5471-5484.

http://dx.doi.org/10.1016/S0040-4020(98)00227-0

[6] Hong, B-C.; Wu, M-F.; Tseng, H-C.; Huang, G-F.; Su, C-F.; Liao, J-H. Organocatalytic asymmetric Robinson annulation of a,b-unsaturated aldehydes: applications to the total synthesis of. Palitantin. J. Org. Chem., 2007, $72,8459-8471$.

http://dx.doi.org/10.1021/jo701477v PMID: 17919000

[7] Valero, G.; Schimer, J.; Cisarova, I.; Vesely, J.; Moyano, A.; Rios, R. Highly enantioselective organocatalytic synthesis of piperidines. Formal synthesis of. Paroxetine. Tetrahedron Lett., 2009, 50, 1943-1946.

http://dx.doi.org/10.1016/j.tetlet.2009.02.049

[8] Michrowska, A.; List, B. Concise synthesis of ricciocarpin A and discovery of a more potent analogue. Nat. Chem., 2009, 1(3), 225-228. http://dx.doi.org/10.1038/nchem.215 PMID: 21378852

[9] Hong, B-C.; Kotame, P.; Tsai, C-W.; Liao, J-H. Enantioselective total synthesis of (+)-conicol via cascade three-component organocatalysis. Org. Lett., 2010, 12(4), 776-779. http://dx.doi.org/10.1021/o1902840x PMID: 20078081

[10] Ren, Q.; Sun, S.; Huang, J.; Li, W.; Wu, M.; Guo, H.; Wang, J. An enantioselective cascade reaction between $\alpha, \beta$-unsaturated aldehydes and malonic half-thioesters: a rapid access to chiral $\delta$-lactones. Chem. Commun.(Camb.), 2014, 50(46), 6137-6140.

http://dx.doi.org/10.1039/C4CC01736F PMID: 24776538

[11] Yu, M.S.; Lantos, I.; Peng, Z-Q.; Yu, J.; Cacchio, T. Asymmetric synthesis of (-)-paroxetine using PLE hydrolysis. Tetrahedron Lett., 2000, 41, 56475651.

http://dx.doi.org/10.1016/S0040-4039(00)00942-4

[12] Hayashi, Y.; Koshino, S.; Ojima, K.; Kwon, E. Pot Economy in the total synthesis of estradiol methyl ether by using an organocatalyst. Angew. Chem. Int. Ed.Engl., 2017, 56(39), 11812-11815.

http://dx.doi.org/10.1002/anie.201706046 PMID: 28749046

[13] Koshino, S.; Kwon, E.; Hayashi, Y. Total synthesis of estradiol methyl ether and its five-pot synthesis with an organocatalyst. Eur. J. Org. Chem., 2018, 5629-5638.

http://dx.doi.org/10.1002/ejoc.201800910

[14] Liu, K.; Chougnet, A.; Woggon, W-D. A short route to alpha-tocopherol. Angew. Chem. Int. Ed. Engl., 2008, 47(31), 5827-5829. http://dx.doi.org/10.1002/anie.200801765 PMID: 18576461

[15] Pelšs, A.; Gandhamsetty, N.; Smith, J.R ; Mailhol, D ; Silvi, M.; Watson, A.J.A.; Perez-Powell, I.; Prévost, S.; Schützenmeister, N.; Moore, P.R.; Aggarwal, V.K. Reoptimization of the organocatalyzed double aldol domino process to a key enal intermediate and its application to the total synthesis of $\delta^{12}$-prostaglandin $\mathbf{J}_{3}$. Chemistry, 2018, 24(38), 9542-9545. http://dx doi.org/10.1002/chem 201802498 PMID: 29774967

[16] Rueping, M.; Antonchick, A.P.; Theissmann, T. A highly enantioselective Brønsted acid catalyzed cascade reaction: organocatalytic transfer hydrogenation of quinolines and their application in the synthesis of alkaloids. Angew. Chem. Int. Ed. Engl., 2006, 45(22), 3683-3686. http://dx.doi.org/10.1002/anie.200600191 PMID: 16639754

[17] Nagata, K.; Nishimura, K.; Yokoya, M.; Itoh, T. Enantioselective syntheses of ent-sedridine and (+)-coniine via proline-catalyzed Mannich reaction. Heterocycles, 2006, 70, 335-344.

http://dx.doi.org/10.3987/COM-06-S(W)29

[18] (a) Chadha, N.; Silakari, O. Indoles as therapeutics of interest in medicinal chemistry: bird's eye view. Eur. J. Med. Chem., 2017, 134, 159-184. http://dx.doi.org/10.1016/j.ejmech.2017.04.003 PMID: 28412530

(b) Connon, R.; Guiry, P.J. Recent advances in the development of onepot/multistep syntheses of 3,4-annulated indoles. Tetrahedron Lett., 2020, 61, 151696-151704

http://dx.doi.org/10.1016/j.tetlet.2020.151696

[19] Jones, S. B. Simmons, B.; MacMillan, D.W C. Nine-step enantioselective total synthesis of (+)-minfiensine. J. Am. Chem. Soc., 2009, 131(38), 1360613607 .

http://dx.doi.org/10.1021/ja906472m PMID: 19725517 